\title{
Florilège de Perceforest, Extraits choisis, édités et traduits par Gilles Roussineau
}

\author{
Maria Colombo Timelli
}

\section{(2) OpenEdition}

\section{Journals}

\section{Édition électronique}

URL : http://journals.openedition.org/studifrancesi/14945

DOI : 10.4000/studifrancesi. 14945

ISSN : 2421-5856

\section{Éditeur}

Rosenberg \& Sellier

\section{Édition imprimée}

Date de publication : 1 décembre 2018

Pagination : 477

ISSN : 0039-2944

\section{Référence électronique}

Maria Colombo Timelli, « Florilège de Perceforest, Extraits choisis, édités et traduits par gilles

Roussineau », Studi Francesi [En ligne], 186 (LXII | III) | 2018, mis en ligne le 01 janvier 2019, consulté le 06 janvier 2021. URL : http://journals.openedition.org/studifrancesi/14945 ; DOI : https://doi.org/ 10.4000/studifrancesi. 14945

Ce document a été généré automatiquement le 6 janvier 2021.

\section{(c) (i) ()}

Studi Francesi è distribuita con Licenza Creative Commons Attribuzione - Non commerciale - Non opere derivate 4.0 Internazionale. 


\title{
Florilège de Perceforest, Extraits choisis, édités et traduits par Gilles Roussineau
}

\author{
Maria Colombo Timelli
}

\section{RÉFÉRENCE}

Florilège de Perceforest, Extraits choisis, édités et traduits par Gilles RoussineAu, Genève, Droz, 2017, «Texte courant» 4, 694 pp.

1 Après avoir édité en 13 tomes la somme que représentent les six parties de Perceforest, «la plus vaste composition en prose du Moyen Âge» (p. vII), Gilles Roussineau offre une anthologie de vingt-quatre extraits, accompagnés de traduction en français moderne. La Présentation fournit, en une trentaine de pages, une information synthétique mais complète sur quelques questions fondamentales: le cadre narratif d'une œuvre foisonnante, qui rattache le cycle d'Alexandre à la matière arthurienne, la tradition manuscrite et imprimée, échelonnée entre $\mathrm{Xv}^{\mathrm{e}}$ et $\mathrm{XVI}^{\mathrm{e}}$ siècle, les critères ayant présidé au choix des fragments retenus et leur contenu. La longueur des textes varie de moins de dix pages à plus de cent, en fonction de l'intérêt des différents passages ou de leur degré d'autonomie au sein du roman, dans le but de montrer «la variété des talents de l'auteur» (p. XI); c'est pourquoi on verra quelques aventures d'Alexandre alternant avec des passages «arthuriens» ou encore avec la description des «curiosités de la nature», tels les célèbres poissons-chevaliers; sont aussi repris trois longs morceaux relativement isolés à l'intérieur de la compilation: le paradis du roi Aroés de la Roide Montagne, la «Belle endormie» et le «Conte de la Rose».

2 G.R., qui connaît mieux que quiconque son texte, n'hésite pas à reconnaître la difficulté que celui-ci représente pour le lecteur d'aujourd'hui, qui «peut parfois être dérouté ou même rebuté par la prolifération des aventures» racontées dans Perceforest (p. x). On lui sera donc particulièrement reconnaissant d'avoir consacré une partie de son temps - 
parallèlement au très savant recueil de "variantes inédites» qu'il vient de publier chez le même éditeur («TLF» 647) - à un florilège bilingue passionnant, où la traduction en français moderne facilitera l'accès à un des textes représentatifs de cette fin du Moyen Âge qui appréciait les sommes romanesques, et encore davantage celles où les matières voisinent, comme ici, dans une mosaïque aux couleurs les plus bigarrées. 